\title{
First Principles Study of Rare Earth Mononitrides ScN and YN under Pressure
}

\author{
R. Yagoub ${ }^{1, \ddagger}$, A. Hadjfatah², S. Louhibi-Fasla 2, , S. Daoud ${ }^{3}$, S. Bahlouli ${ }^{1}$, A. Haichour ${ }^{2}$, C. Zegadi2,** \\ ${ }^{1}$ Laboratory of Plasma Physics Materials Conductor and their Applications LPPMCA, USTO El-Mnaouer, \\ Oran 31000, Algeria \\ ${ }^{2}$ Laboratory of Micro and Nanophysics (LaMiN), National Polytechnic School of Oran, ENP Oran-Maurice AUDIN, \\ BP1523 El-Mnaouer, Oran 31000, Algeria \\ ${ }^{3}$ Laboratoire Matériaux et Systèmes Electroniques, Université Mohamed Elbachir El Ibrahimi de Bordj Bou \\ Arreridj, Bordj Bou Arreridj 34000, Algérie
}

(Received 21 August 2020; revised manuscript received 15 October 2020; published online 25 October 2020)

\begin{abstract}
We report the study of high-pressure phases of $\mathrm{YN}$ and $\mathrm{ScN}$ compounds, using a recent version of the full potential linear muffin-tin orbital (FPLMTO) method, which enables an accurate treatment of the interstitial regions. The local density approximation (LDA) was used for the exchange and correlation energy density functional. Calculations are given for lattice parameters, bulk modulus and its first derivatives in different structures. Under compression, we found that $\mathrm{ScN}$ transforms from NaCl-type structure (B1) to Beta-Sn-type (A5) at a pressure of around $301.3 \mathrm{GPa}$, with a direct energy gap at $\Gamma$ of about $0.108 \mathrm{eV}$. This transition $\mathrm{B} 1$ to A5 takes place at a lower pressure than the well-known transition NaCl-type structure (B1) to CsCl-type structure (B2) (found here to be $412 \mathrm{GPa}$ ). Our calculations also show that YN transforms from B1 to B2 at a pressure of around $198.5 \mathrm{GPa}$.
\end{abstract}

Keywords: DFT, Rare earth mononitrides (RENs), Structural phase transition, FPLMTO.

DOI: 10.21272/jnep.12(5).05009

PACS numbers: 31.15.es, 71.15.Mb, 71.20.Eh

\section{INTRODUCTION}

Transition metal mononitrides (TMNs) have become the subject of much attention recently. The scandium nitride $(\mathrm{ScN})$ and yttrium nitride (YN) binary compounds are two TMNs, which crystallize in NaCl-type structure (B1) at normal conditions $[1,2]$ with an indirect $\Gamma$-X fundamental bandgap. These binary semiconducting compounds exhibit some particular physical properties such as high melting point (in excess of $\sim 2600^{\circ} \mathrm{C}$ for $\mathrm{ScN}$ [3]) and high hardness [1].

Due to these particular physical properties $\mathrm{ScN}$ and YN have particular technological applications as hard coatings for cutting tools and possible potential for applications in magnetic recording and sensing [1], as well as refractory electronics and plasmonics materials [3]. The small lattice mismatches between $\mathrm{ScN}$ and YN semiconducting compounds and the group-IIIB nitrides plays an important role in the synthesis of mixed materials in the form of alloys and super-lattices [4], which can provide a viable alternative to $\mathrm{GaInN}$ systems for different applications especially in solar cells and lightemitting devices fabrication [2].

Based on first-principles plane-wave approach, Tahri et al. [2] have studied the vibrational and thermal properties of both $\mathrm{ScN}$ and $\mathrm{YN}$ semiconducting compounds using quasi-harmonic approximation calculations plus anharmonic effects. Their results on thermal expansivity show that there are significant anharmonic effects in both $\mathrm{ScN}$ and $\mathrm{YN}$ compounds.

Using first principles calculation with the density functional theory, Meenaatci et al. [5] have investigated high-pressure structural phase transition, elastic constants, and electronic properties of group III-nitrides

\footnotetext{
†rym_yagoubi@yahoo.fr

§ souad.fasla@enp-oran.dz / fasbenplast@yahoo.fr

** chawki.zegadi@enp-oran.dz
}

(ScN, YN and LaN). Their results also show that the cubic NaCl-type structure is the most energetically stable structure at ambient pressure.

The phase stability, electronic structure and mechanical properties of two quasi-binary ceramic systems, $\mathrm{Ti}_{1-x} \mathrm{Sc}_{x} \mathrm{~N}$ and $\mathrm{Ti}_{1-x} \mathrm{Y}_{x} \mathrm{~N}(0 \leq x \leq 1)$, were studied by Adhikari et al. [6] using first principles methods based on density functional theory, cluster expansion formalism, and Monte Carlo techniques. The application of hydrostatic compression to crystals often results in a transformation from the most energetically stable structure to another phase and enhanced hardness of the materials. In the present study, first principles total energy calculations were used to investigate the equilibrium structural parameters, the pressure-induced phase transitions and electronic properties of $\mathrm{ScN}$ and $\mathrm{YN}$ semiconducting compounds. Several possible phases for $\mathrm{ScN}$ and $\mathrm{YN}$ including $\mathrm{NaCl}$-type (rock-salt (B1)), zincblende (B3), CsCl-type (B2), wurtzite (B4), CuAu-type (L10), hexagonal close packed (HCP or A3), and $\beta$-Sntype (A5) structures have been considered in our calculations. The paper is organized as follows. After a brief description of the method in Section 2, we present in Section 3 the different results on the structural parameters, structural phase transition of both $\mathrm{ScN}$ and YN compounds as well as the electronic properties. And conclusions are summarized in Section 4.

\section{COMPUTATIONAL DETAILS}

The calculations presented in this work were performed by full potential linear muffin-tin orbital (FPLMTO) method within the framework of density functional theory (DFT). The exchange-correlation has 
been accounted for LDA using the exchange-correlation potential calculated by Perdew et al. [7]. The available computer code lmtART [8] was used in the present work. Using FPLMTO method as implemented in the lmtART [8] code needs some requirements such as: the maximal angular momentum for the expansion of the charge density and the potential in spherical harmonics, the number of plane waves (NPLW), the total cut-off energy, as well as the muffin-tin radius (RMT) values. In all cases, the maximal angular momentum for the expansion of the charge density and the potential in spherical harmonics was fixed to $l_{\max }=6$. The number of plane waves (NPLW), total cut-off energies, and the muffin-tin radius (RMT) values used in our calculation for both $\mathrm{ScN}$ and YN materials are summarized in Table 1.

Table 1 - Plane wave number (NPLW), cut-off energy (in Ry) and the muffin-tin radius (RMT) (in a.u.) used in our calculation for both $\mathrm{ScN}$ and $\mathrm{YN}$ semiconducting compounds

\begin{tabular}{|c|c|c|c|c|}
\hline \multirow[b]{2}{*}{$\begin{array}{l}\text { Struc } \\
\text { ture }\end{array}$} & \multicolumn{2}{|c|}{ NPLW } & \multicolumn{2}{|c|}{$E_{\text {cut }}(\mathrm{Ry})$} \\
\hline & $\mathrm{ScN}$ & YN & $\mathrm{ScN}$ & $\begin{array}{c}\mathrm{YN} \\
(s, p, d)\end{array}$ \\
\hline $\begin{array}{l}\mathrm{NaCl} \\
\text { (B1) }\end{array}$ & 2974 & 2974 & 112.44 & $\begin{array}{c}11.7,17.1, \\
24.9\end{array}$ \\
\hline $\begin{array}{l}\mathrm{CsCl} \\
\text { (B2) }\end{array}$ & 3070 & 3070 & 118.53 & $\begin{array}{c}11.3,15.5, \\
22.5\end{array}$ \\
\hline $\begin{array}{l}\mathrm{ZnS} \\
\text { (B3) }\end{array}$ & 5064 & 5064 & 140.68 & $\begin{array}{c}13.3,20.0, \\
27.9\end{array}$ \\
\hline $\begin{array}{c}\mathrm{Wz} \\
\text { (B4) }\end{array}$ & 12850 & 14844 & 163.72 & $\begin{array}{c}13.4,18.9, \\
27.8\end{array}$ \\
\hline $\begin{array}{l}\mathrm{CuAu} \\
\left(\mathrm{L}_{0}\right)\end{array}$ & 3308 & - & 127.05 & - \\
\hline $\begin{array}{l}\mathrm{HCP} \\
\text { (A3) }\end{array}$ & - & 11882 & - & $\begin{array}{c}12.2,17.7 \\
25.7\end{array}$ \\
\hline $\begin{array}{l}\beta \text {-Sn } \\
\text { (A5) }\end{array}$ & 2090 & 2090 & 86.28 & $\begin{array}{c}11.5,17.3, \\
25.7\end{array}$ \\
\hline
\end{tabular}

\begin{tabular}{|c|c|c|c|c|}
\hline \multirow{2}{*}{$\begin{array}{c}\text { Struc- } \\
\text { ture }\end{array}$} & \multicolumn{4}{|c|}{ RcN (u.a.) } \\
\cline { 2 - 5 } & $\mathrm{Sc}$ & $\mathrm{N}$ & $\mathrm{Y}$ & $\mathrm{N}$ \\
\hline $\begin{array}{c}\mathrm{NaCl} \\
(\mathrm{B} 1)\end{array}$ & 2.346 & 1.843 & 2.56 & 1.931 \\
\hline $\begin{array}{c}\mathrm{CsCl} \\
(\mathrm{B} 2)\end{array}$ & 2.518 & 1.979 & 2.648 & 1.939 \\
\hline $\mathrm{ZnS}(\mathrm{B} 3)$ & 2.141 & 2.141 & 2.401 & 1.811 \\
\hline $\mathrm{Wz}(\mathrm{B} 4)$ & 2.124 & 1.738 & 2.385 & 1.799 \\
\hline $\begin{array}{c}\mathrm{CuAu} \\
(\mathrm{L} 10)\end{array}$ & 2.494 & 2.001 & - & - \\
\hline $\begin{array}{c}\mathrm{HCP} \\
(\mathrm{A} 3)\end{array}$ & - & - & 2.479 & 1.87 \\
\hline $\begin{array}{c}\beta-\mathrm{Sn} \\
(\mathrm{A} 5)\end{array}$ & 2.31 & 1.815 & 2.491 & 1.803 \\
\hline
\end{tabular}

For structures with cubic symmetry (NaCl-type (B1), CsCl-type (B2) and ZnS-type (B3)), only one structural parameter (the lattice constant $a$ ) is used to describe the unit cell. The structures with tetragonal symmetry (CuAu-type (L10) and $\beta$-Sn-type (A5)) have two structural parameters ( $a, c$ (or cla ratio)), which are used to describe the unit cell, while for other phases having hexagonal symmetry (wurtzite (B4) and HCP (A3)), three structural parameters $(a, c / a$ ratio and internal parameter $(u))$ are used to describe the unit cell. When $z=0.5$, it can be noted that the CuAu-type ( $\left.\mathrm{L}_{0}\right)$ structure is a particular case of $\mathrm{PbO}$-type (B10) structure.

\section{DISCUSSION OF RESULTS}

\subsection{EOS Parameters}

Usually, the structural parameters in the ground state are determined by calculating the total energy at different volumes $(E-V)$ around the equilibrium one for the material of interest. They can also be predicted from $a b$-initio calculation of the pressure-unit cell volume $(P-V)$ data. In order to obtain the structural parameters of $\mathrm{ScN}$ and $\mathrm{YN}$ compounds in different phases, the energy-unit cell volume $(E-V)$ data were used here. The equilibrium lattice volume $V_{0}$, bulk modulus $B_{0}$ and the pressure derivative of the bulk modulus $B_{0}{ }^{\prime}$ have been computed by minimizing the total energy by means of Murnaghan's equation of state (EOS), which is expressed as follow [9]:

$$
E(V)=E\left(V_{0}\right)+\frac{B_{0} V}{B_{0}^{\prime}}\left[\frac{\left(V_{0} / V\right)^{B_{0}^{\prime}}}{B_{0}^{\prime}-1}+1\right]-\frac{B_{0} V_{0}}{B_{0}^{\prime}-1},
$$

where $E_{0}$ is the energy of the ground state corresponding to the equilibrium volume $V_{0}, B_{0}{ }^{\prime}\left(B_{0^{\prime}}=\partial B / \partial P\right.$ at $P=0)$ is the pressure derivative of the bulk modulus $B$.

The bulk modulus $B$ is a quantity which defines the strength of bonds in solids; it is a measure of resistance to external deformation [9], it is usually increases as external pressure enhances. Fig. 1 and Fig. 2 present the variation of the total energy as a function of the unit cell volume in different structures of $\mathrm{ScN}$ and $\mathrm{YN}$ semiconducting compounds, respectively. From Fig. 1 and Fig. 2, the lowest minimum NaCl-type phase energy was observed for both $\mathrm{ScN}$ and $\mathrm{YN}$ semiconducting compounds, while the total energies of A3, A5, B2, B3, $\mathrm{B} 4$, and $\mathrm{L} 10$ phases are much higher. It can be noted that the same ground-state configuration was also observed for other compounds, such as scandium phosphide $(\mathrm{ScP})$, scandium arsenide ( $\mathrm{ScAs}$ ) and scandium antimonide ( $\mathrm{ScSb})$ [10].

Our results of the equilibrium structural parameters, bulk modulus and the pressure derivative of the bulk modulus of both $\mathrm{ScN}$ and $\mathrm{YN}$ semiconducting compounds in B1, B2, B3 and B4 phases are summarized in Table 2 and Table 3 together with those of the literature [5, 15-20]. We notice that our values of different parameters are in general in agreement with those obtained from other calculations $[5,10,11,13,14]$ and experimental works $[12,15]$

From the data summarized in Table 2 and Table 3 we can observe that the lattice constant $a_{0}$ of both $\mathrm{ScN}$ and YN compounds in different configurations is in general in good agreement compared to experimental values $[12,15]$ and other theoretical results $[5,10,11$, $13,14]$. For example, our obtained value (4.9383 $\AA$ ) of the cubic ZnS-type structure underestimates the theoretical value $(4.939 \AA$ ) reported by Tebboune et al. [10] by less than $0.02 \%$, while our value $(4.864 \AA$ ) of the cubic NaCl-type phase underestimates the experimental result ( $4.877 \AA$ ) reported by Soto et al. [15] by around $0.27 \%$. 


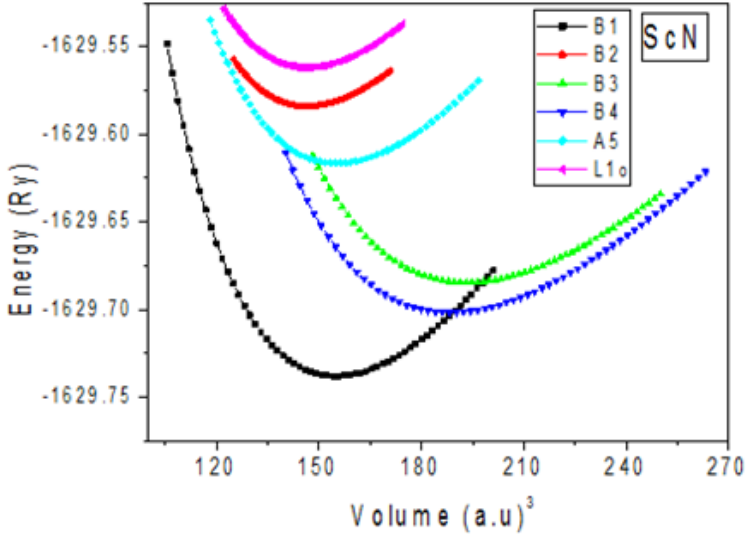

Fig. 1 - Total energy versus volume for different phases of ScN semiconducting compound

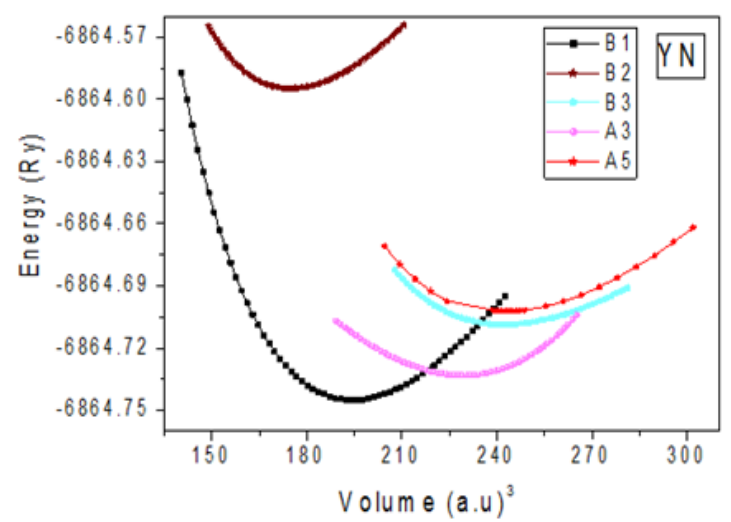

Fig. 2 - Total energy versus volume for different phases of YN compound

Table 2 - EOS parameters of ScN and YN at zero-pressure in comparison with other data of the literature

\begin{tabular}{|c|c|c|c|c|c|}
\hline \multicolumn{2}{|c|}{ Parameters } & \multicolumn{2}{|c|}{$\mathrm{NaCl}(\mathrm{B} 1)$} & \multicolumn{2}{|c|}{$\mathrm{CsCl}(\mathrm{B} 2)$} \\
\hline & & $\mathrm{ScN}$ & $\mathrm{YN}$ & $\mathrm{ScN}$ & $\mathrm{YN}$ \\
\hline & This work & 4.512 & 4.864 & 2.78 & 2.960 \\
\hline $\begin{array}{c}a_{0} \\
(\AA)\end{array}$ & $\begin{array}{l}\text { Other } \\
\text { works }\end{array}$ & $\begin{array}{c}4.435^{\mathrm{a}} \\
4.651^{\mathrm{b}} \\
4.54^{\mathrm{c}} \\
4.501^{\mathrm{d}}\end{array}$ & $\begin{array}{c}4.891^{\mathrm{a}} \\
4.93^{\mathrm{e}} \\
4.93^{\mathrm{f}} \\
4.877^{\mathrm{g}}\end{array}$ & $\begin{array}{c}2.961^{\mathrm{a}} \\
2.926^{\mathrm{b}} \\
2.81^{\mathrm{c}}\end{array}$ & $\begin{array}{c}3.014^{\mathrm{a}} \\
3.01^{\mathrm{e}} \\
3.00^{\mathrm{f}}\end{array}$ \\
\hline & This work & 202.42 & 176.23 & 188.44 & 170.05 \\
\hline $\begin{array}{c}B_{0} \\
(\mathrm{GPa})\end{array}$ & $\begin{array}{l}\text { Other } \\
\text { works }\end{array}$ & $\begin{array}{c}220^{\mathrm{a}} \\
210.36^{\mathrm{b}} \\
201^{\mathrm{c}} \\
182 \pm 40^{\mathrm{d}}\end{array}$ & $\begin{array}{l}162^{\mathrm{a}} \\
157^{\mathrm{e}} \\
151^{\mathrm{f}}\end{array}$ & $\begin{array}{c}180^{\mathrm{a}} \\
159.76, \\
170^{\mathrm{c}}\end{array}$ & $\begin{array}{l}132^{\mathrm{a}} \\
136^{\mathrm{e}} \\
153^{\mathrm{f}}\end{array}$ \\
\hline & This work & 3.94 & 3.93 & 4.08 & 4.30 \\
\hline$B_{0}^{\prime}$ & $\begin{array}{l}\text { Other } \\
\text { works }\end{array}$ & $\begin{array}{c}3.45^{\mathrm{a}} \\
3.123^{\mathrm{b}} \\
3.31^{\mathrm{c}} \\
\end{array}$ & $\begin{array}{l}3.78^{\mathrm{a}} \\
3.50^{\mathrm{e}} \\
3.86^{\mathrm{f}} \\
\end{array}$ & $\begin{array}{c}4.15^{\mathrm{a}} \\
3.034^{\mathrm{b}} \\
3.47^{\mathrm{c}}\end{array}$ & $\begin{array}{l}4.06^{\mathrm{a}} \\
4.11^{\mathrm{e}} \\
3.46^{\mathrm{f}} \\
\end{array}$ \\
\hline
\end{tabular}

In Table 2 and Table 3, we present the structural parameters (equilibrium lattice constants $a, c$, and $c / a$, and the internal parameter $u$ ), bulk modulus $B_{0}$ and the pressure derivatives of the bulk modulus $B_{0}{ }^{\prime}$ for $\mathrm{B} 1$, B2, B3 and B4 phases for both $\mathrm{ScN}$ and YN semiconducting compounds. a-Ref. [5] using PP-PAW (GGA), b-Ref. [10] using FPLMTO (LDA), c-Ref. [11], d-Ref. [12] Expt., e-Ref. [13] using FP-LAPW (GGA), f-Ref. [14] using FP-LAPW (GGA), g-Ref. [15] Expt.
Our predicted values of the equilibrium bulk modulus $B_{0}$ and its pressure derivative $B_{0}{ }^{\prime}$ of both $\mathrm{ScN}$ and YN compounds in different structures are also in good agreement compared to the experimental result [12] and other theoretical results $[5,10,11,13,14]$. Our obtained value (202.42 GPa) of $B_{0}$ for $\mathrm{ScN}$ in NaCl-type configuration overestimates the theoretical value of $201 \mathrm{GPa}$ obtained by Takeuchi [11] by less than $0.71 \%$.

Table 3 - EOS parameters of $\mathrm{ScN}$ and $\mathrm{YN}$ semiconducting compounds with B3 and B4 phases in comparison with other data of the literature

\begin{tabular}{|c|c|c|c|c|}
\hline \multicolumn{2}{|c|}{ Parameters } & \multicolumn{2}{|c|}{$\mathrm{ZnS}$ (B3) } & $\mathrm{Wz}(\mathrm{B} 4)$ \\
\hline & & $\mathrm{ScN}$ & $\mathrm{YN}$ & $\mathrm{ScN}$ \\
\hline \multirow{2}{*}{$\begin{array}{l}a_{0} \\
(\AA)\end{array}$} & $\begin{array}{l}\text { This } \\
\text { work }\end{array}$ & 4.9383 & 5.248 & 3.50 \\
\hline & $\begin{array}{l}\text { Other } \\
\text { works }\end{array}$ & $\begin{array}{c}4.939^{b} \\
4.88^{c}\end{array}$ & $5.28^{\mathrm{e}}$ & $\begin{array}{l}3.45^{\mathrm{b}} \\
3.49^{\mathrm{c}} \\
\end{array}$ \\
\hline \multirow{2}{*}{$\begin{array}{c}B_{0} \\
(\mathrm{GPa})\end{array}$} & $\begin{array}{l}\text { This } \\
\text { work }\end{array}$ & 171.23 & 116.51 & 136.37 \\
\hline & $\begin{array}{l}\text { Other } \\
\text { works }\end{array}$ & $\begin{array}{c}145.2^{\mathrm{b}} \\
153^{\mathrm{c}}\end{array}$ & $110^{\mathrm{e}}$ & $\begin{array}{c}132.91^{b} \\
156^{\mathrm{c}}\end{array}$ \\
\hline \multirow{2}{*}{$B_{0}{ }^{\prime}$} & $\begin{array}{c}\text { This } \\
\text { work }\end{array}$ & 3.696 & 5.233 & 3.71 \\
\hline & $\begin{array}{l}\text { Other } \\
\text { works }\end{array}$ & $\begin{array}{c}3.433^{\mathrm{b}} \\
3.34^{\mathrm{c}}\end{array}$ & $4.39^{\mathrm{e}}$ & $\begin{array}{c}3.293^{\mathrm{b}} \\
2.16^{\mathrm{c}}\end{array}$ \\
\hline \multirow[b]{2}{*}{$u$} & $\begin{array}{l}\text { This } \\
\text { work }\end{array}$ & - & - & 0.395 \\
\hline & $\begin{array}{l}\text { Other } \\
\text { works }\end{array}$ & - & - & $\begin{array}{c}0.377^{\mathrm{b}} \\
0.38^{\mathrm{c}}\end{array}$ \\
\hline \multirow{2}{*}{$c / a$} & $\begin{array}{l}\text { This } \\
\text { work }\end{array}$ & - & - & 1.5 \\
\hline & $\begin{array}{l}\text { Other } \\
\text { works }\end{array}$ & - & - & $\begin{array}{c}1.552^{\mathrm{b}} \\
1.6^{\mathrm{c}}\end{array}$ \\
\hline
\end{tabular}

Therefore, as conclusion if taking into account the above experimental and theoretical uncertainties, one can clearly observe that our calculated structural parameters for both $\mathrm{ScN}$ and $\mathrm{YN}$ materials are in reasonable agreement with available experimental results and other theoretical data of the literature. Our results of the structural parameters of both $\mathrm{ScN}$ and $\mathrm{YN}$ materials in three other phases $\left(\mathrm{A} 3, \mathrm{~A} 5\right.$, and $\left.\mathrm{L} 1_{0}\right)$ are presented and summarized in Table 4. Except the results predicted by Berkok et al. [16] for L10 phase, to the best of our knowledge, there are no other data existing in the literature on the structural parameters for both $\mathrm{ScN}$ and $\mathrm{YN}$ compounds in $\mathrm{A} 3$ and $\mathrm{A} 5$ phases.

\subsection{Structural Phase Transition}

To determine the most stable structure at finite pressure and temperature, we have compared the enthalpies $H=E+P V$ of different phases instead of their free energies $G=E+P V-T S$ (since the temperature $T=0 \mathrm{~K})$. The transition pressure $\left(P_{t}\right)$ between the most stable phase (NaCl-type configuration) and other structures was calculated using the enthalpy differences for different phases (A3, A5, B2, B3, and L10) as a function of pressure with respect to the $\mathrm{NaCl}$-type structure. For both $\mathrm{ScN}$ and $\mathrm{YN}$ semiconducting materials, the variation of the enthalpy differences as a function of pressure is plotted in Fig. 3 and Fig. 4, respectively. 
Table 4 - EOS parameters of ScN and YN compounds with $\mathrm{A} 3$, A5 and L10 phases in comparison with other data of the literature, a-Ref. [5]

\begin{tabular}{|c|c|c|c|c|}
\hline $\begin{array}{c}\text { Parame- } \\
\text { ters }\end{array}$ & $\begin{array}{c}\text { HCP } \\
(\mathrm{A} 3)\end{array}$ & $\begin{array}{c}\beta \text {-Sn-type } \\
(\mathrm{A} 5)\end{array}$ & \multicolumn{2}{|c|}{ CuAu-type (L10) } \\
\hline & $\mathrm{YN}$ & $\mathrm{ScN}$ & $\mathrm{YN}$ & $\mathrm{ScN}$ \\
\hline$a_{0}(\AA)$ & 3.9975 & 4.157 & 3.6438 & $\begin{array}{c}3.790, \\
3.734^{\mathrm{a}}\end{array}$ \\
\hline$B_{0}(\mathrm{GPa})$ & 142.41 & 178 & 117.98 & $\begin{array}{c}181.97, \\
198.557^{\mathrm{a}}\end{array}$ \\
\hline$B_{0^{\prime}}$ & 3.92 & 3.52 & 3.65 & $\begin{array}{c}4.34, \\
3.929^{\mathrm{a}}\end{array}$ \\
\hline$u$ & 0.50 & - & - & - \\
\hline$c / a$ & 1.195 & 0.64 & 1.49 & $\begin{array}{c}0.795, \\
0.79^{\mathrm{a}}\end{array}$ \\
\hline
\end{tabular}

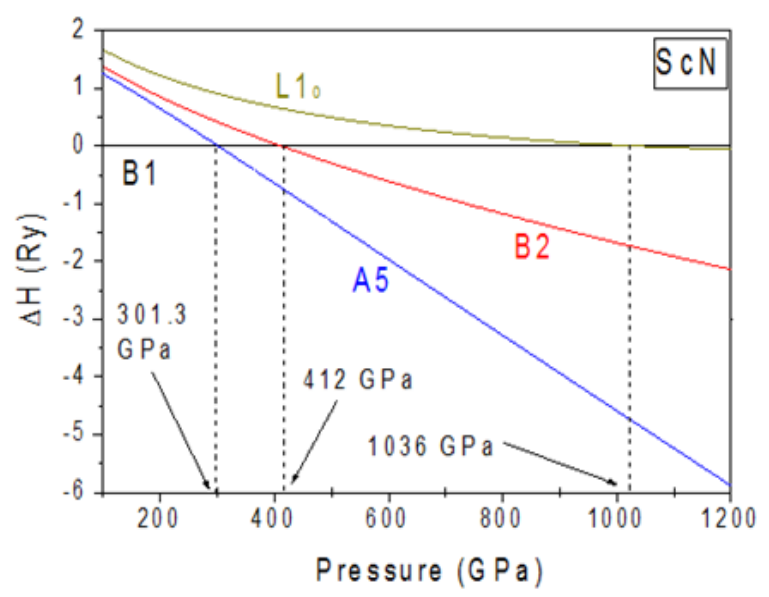

Fig. 3 - Variation of the enthalpy difference $\Delta H$ as a function of pressure for $\mathrm{A} 5, \mathrm{~B} 2$ and $\mathrm{L} 10$ phases of $\mathrm{ScN}$. The reference enthalpy is set for $\mathrm{B} 1$ phase

We note that in the present study of $\mathrm{ScN}$ and $\mathrm{YN}$, the B3, B4, A3 and other structures have been considered in our calculations but were not closed to stability in any range of pressures of interest. The transition pressures were obtained from the enthalpy differences curves crossing. Our calculations show that a transition from NaCl-type (B1) to CsCl-type (B2) may occur at pressures of $\sim 412 \mathrm{GPa}$ for $\mathrm{ScN}$ and $\sim 198.5 \mathrm{GPa}$ for YN. Our results of the transition pressure $\left(P_{t}\right)$ from $\mathrm{NaCl}$-type (B1) to CsCl-type (B2) configuration of both $\mathrm{ScN}$ and $\mathrm{YN}$ semiconducting compounds are summarized in Table 5 together with those of the literature [10, 11, 13, 14, 16-20].

From Table 5, it can be observed that our values of the phase transition pressure $P_{t}(\mathrm{GPa})$ of both $\mathrm{ScN}$ and YN semiconducting compounds are in general slightly higher than other theoretical results $[10,11,13,14,16$ $20]$. In the present work, we have also predicted some other transitions. For ScN semiconducting compound, a new phase transition from B1 to A5 was found at around $301.3 \mathrm{GPa}$. This transition occurs at a lower pressure than the well-known NaCl-type structure (B1) to CsCl-type structure (B2). To the best of our knowledge, there are no other data existing in the literature on the $\mathrm{B} 1$ to $\mathrm{A} 5$ transition for $\mathrm{ScN}$ compound.

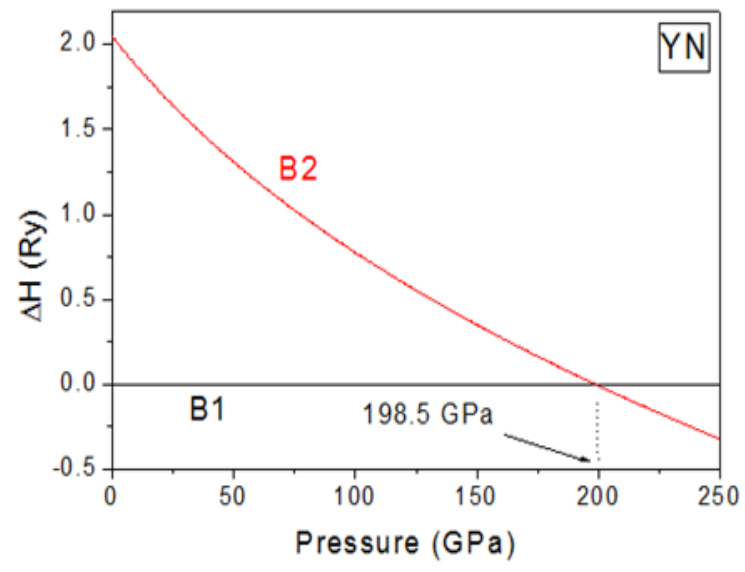

Fig. 4 - Enthalpy difference $\Delta H$ versus pressure for B2 phase of YN compound. The reference enthalpy is set for the rocksalt phase (B1)

Table 5 - Calculated values of the phase transition pressure $P_{t}(\mathrm{GPa})$ of both $\mathrm{ScN}$ and $\mathrm{YN}$ semiconducting compounds with other theoretical data $[10,11,13,14,16-20]$ of the literature. a-Ref. [10], b-Ref. [11], c-Ref. [17], d-Ref. [18], e-Ref. [19], f-Ref. [13], g-Ref. [14], h-Ref. [20] LDA, i-Ref. [20] GGA, j-Ref. [16] using FPLMTO method (LDA)

\begin{tabular}{|c|c|c|}
\hline Compound & This work & Other works \\
\hline ScN & 412 & $\begin{array}{c}332.75^{\mathrm{a}}, 341^{\mathrm{b}}, 365.87^{\mathrm{c}} \\
364.32^{\mathrm{d}}, 368.46^{\mathrm{e}}, 324^{\mathrm{j}}\end{array}$ \\
\hline YN & 198.5 & $\sim 138^{\mathrm{f}}, 133.94^{\mathrm{g}}, 116^{\mathrm{h}}, 131^{\mathrm{i}}$ \\
\hline
\end{tabular}

We also report that for $\mathrm{ScN}$ a transition pressure from $\mathrm{B} 1$ to L10 occurs at around $1036 \mathrm{GPa}$.

\section{CONCLUSIONS}

In summary, we have carried out first-principles band structure and total-energy calculations of both $\mathrm{ScN}$ and $\mathrm{YN}$ semiconducting compounds for NaCl-type, CsCl-type, cubic-ZnS-type, wurtzite-type, CuAu-type, HCP-type, and $\beta$-Sn-type configurations by an ab-initio PLW-FPLMTO method, within the local density approximation (LDA). The ground state properties such as the equilibrium lattice parameter, the bulk modulus and its pressure derivative were predicted, analyzed and compared with other available experimental and theoretical data. The main results of the present work can be summarized as follows.

We confirm that the rock salt is the ground state configuration for the two binary $\mathrm{ScN}$ and $\mathrm{YN}$ compounds. Our results clearly indicate that there is a structural transition from $\mathrm{NaCl}$ to $\mathrm{CsCl}$ type configuration at $412 \mathrm{GPa}$ and $198.5 \mathrm{GPa}$, respectively, for $\mathrm{ScN}$ and YN confirming experimental suggestions. In general, our findings are slightly higher than other theoretical results of the literature.

Our most important result for $\mathrm{ScN}$ is that concerned with the possibility of phase transition from $\mathrm{NaCl}$-type structure (B1) to $\beta$-Sn-type (A5) at a pressure of around $301.3 \mathrm{GPa}$. In the absence of experimental findings and support regarding this transition, our results can serve as a prediction for future investigations. 


\section{REFERENCES}

1. T-Y. Lü, M-C. Huang, Chinese Phys. 16 No 1, 62 (2007).

2. S. Tahri, A. Qteish, I.I. Al-Qasir, N. Meskini, J. Phys. Condens. Matter. 24 No 3, 035401 (2012).

3. B. Biswas, B. Saha, Phys. Rev. Mater. 3 No2, 020301 (2019).

4. M-E. Little, M-E. Kordesch, Appl. Phys. Lett. 78, 2891 (2001).

5. A.T. Asivini Meenaatci, R. Rajeswarapalanichamy, K. Iyakutti, Phase Transit. 86, 570 (2012).

6. V. Adhikari, N.J. Szymanski, I. Khatri, D. Gall, S.V. Khare, Thin Solid Films 688, 137284 (2019).

7. J.P. Perdew, Y. Wang, Phys. Rev. B 46, 12947 (1992).

8. S.Y. Savrasov, Phys. Rev. B 54, 16470 (1996)

9. A. Rastogi, P. Rajpoot, U.P. Verma, Bull. Mater. Sci. 42, 112 (2019).

10. A. Tebboune, D. Rached, A. Benzair, N. Sekkal, A.H. Belbachir, Phys. Status Solidi B 243, 2788 (2006).

11. N. Takeuchi, Phys. Rev. B 65, 045204 (2002).
12. D. Gall, I. Petrov, N. Hellgren, L. Hulman, J-E. Sundgren, J.E. Greene, J. Appl. Phys. 84, 6034 (1998).

13. L. Mancera, J.A. Rodríguez, N. Takeuchi, J. Phys. Condens. Matter. 15 No17, 2625 (2003).

14. S. Zerroug, F. Ali Sahraoui, N. Bouarissa, Appl.Phys. A 97, 345 (2009).

15. G. Soto, M.G. Moreno-Armenta, A. Reyes-Serrato, Comput. Mater. Sci. 42, 8 (2008).

16. H. Berkok, A. Tebboune, M.N. Belkaid, Physica B 406, 3836 (2011).

17. P. Bhardwaj, S. Singh, Procedia Comput. Sci. 57, 160 (2015).

18. A. Maachou, B. Amrani, M. Driz, Physica B 388, 384 (2007).

19. P. Bhardwaj, S. Singh, N.K. Gaur, Mat. Res. Bull. 44, 1366 (2009).

20. A. Gueddim, N. Bouarissa, L. Gacem, A. Villesuzanne, Chinese J. Phys. 56, 1816 (2018).

\title{
Першопринципне дослідження рідкоземельних мононитридів $\mathrm{ScN}$ i YN під тиском
}

R. Yagoub ${ }^{1}$, A. Hadjfatah 2 , S. Louhibi-Fasla 2 , S. Daoud ${ }^{3}$, S. Bahlouli', A. Haichour ${ }^{2}$, C. Zegadi²

${ }^{1}$ Laboratory of Plasma Physics Materials Conductor and their Applications LPPMCA, USTO El-Mnaouer, Oran 31000, Algeria

${ }^{2}$ Laboratory of Micro and Nanophysics (LaMiN), National Polytechnic School of Oran, ENP Oran-Maurice AUDIN, BP1523 El-Mnaouer, Oran 31000, Algeria

${ }^{3}$ Laboratoire Matériaux et Systèmes Electroniques, Université Mohamed Elbachir El Ibrahimi de Bordj Bou Arreridj, Bordj Bou Arreridj 34000, Algérie

\begin{abstract}
Ми повідомляемо про дослідження фаз високого тиску сполук $\mathrm{YN}$ та $\mathrm{ScN}$, використовуючи останню версію методу FPLMTO, який забезпечуе точну обробку міжвузлових областей. Наближення локальної густини (LDA) застосовували для обмінної та кореляційної функціональної густини енергії. Приведено розрахунки параметрів решітки, об'ємного модуля та його перших похідних у різних структурах. Ми виявили, що при стисненні $\mathrm{ScN}$ перетворюеться із структури типу $\mathrm{NaCl}$ (B1) у тип $\beta$ - $\mathrm{Sn}(\mathrm{A} 5)$ під тиском близько 301,3 ГПа з прямою забороненою зоною приблизно рівною 0,108 еВ. Цей перехід від В1 до А5 відбувається за нижчого тиску, ніж добре відомий перехід структури типу $\mathrm{NaCl}$ (B1) у структуру типу $\mathrm{CsCl}$ (B2) (виявлене в статті значення складає 412 ГПа). Наші розрахунки також показують, що YN перетворюеться з В1 на В2 під тиском близько 198,5 ГПа.
\end{abstract}

Ключові слова: DFT, Рідкоземельні мононітриди, Структурний фазовий перехід, FPLMTO. 